\title{
THE RELATIONSHIP BETWEEN PERSONAL HYGIENE AND SOIL TRANSMITTED HELMINTHS IN VEGETABLE FARMERS IN GIANYAR DISTRICT
}

\author{
HUBUNGAN ANTARA PERSONAL HYGIENE \\ DENGAN INFEKSI TELUR CACING USUS (SOIL \\ TRANSMITTED HELMINTHS) PADA PETANI SAYUR \\ DI KABUPATEN GIANYAR
}

\author{
Sri Idayani ${ }^{1}$, Ni Luh Nova Dilisca Dwi Putri' ${ }^{2}$ M. Fairuz Abadi ${ }^{3}$ \\ Program Studi Teknologi Laboratorium Medis Program Diploma Tiga \\ STIKes Wira Medika Bali, Indonesia
}

\begin{abstract}
ABSTRAK
Soil Transmitted Helminths (STH) merupakan cacing golongan nematoda usus yang menginfeksi manusia yang menelan telurnya melalui rute fekal oral. Infeksi cacing Soil Transmitted Helminths (STH) ditransmisikan melalui telur dan larva yang terdapat pada feses manusia yang kemudian mengkontaminasi tanah area lingkungan yang memiliki sanitasi yang buruk. Dampak yang ditimbulkan oleh penyakit kecacingan antara lain, yaitu kekurangan gizi, gangguan tumbuh kembang dan gangguan kognitif pada anak, dan pada orang dewasa bisa menurunkan produktifitas kerja. Kejadian kecacingan banyak ditemukan terutama pada penduduk yang berada di daerah pedesaan, khususnya pada petani. Penularan STH pada petani sayur terjadi melalui air dan lumpur yang digunakan dalam budidaya sayuran. prevalensi STH didukung oleh keadaan alam yang cocok, personal hygiene dan sanitasi lingkungan yang rendah khususnya di lingkungan pertanian sayur. Penelitian ini bertujuan untuk mengetahui adanya hubungan antara personal hygiene dengan infeksi telur cacing usus (Soil Transmitted Helmint) petani sayur di Kabupaten Gianyar. Jenis penelitian yang digunakan dalam penelitian ini adalah penelitian deskriptif korelatif dengan pendekatan cross sectional study yang bertujuan untuk mengetahui hubungan antara personal hygiene dengan infeksi cacing usus (Soil Transmitted Helmint) pada petani sayur di Kabupaten Gianyar. Hasil penelitian menunjukkan bahwa kondisi personal hygiene petani sayur di Kabupaten Gianyar buruk (83,3\% )dan kejadian infeksi kecacingan pada petani sayur di Kabupaten Gianyar adalah 20\%. Tidak terdapat hubungan antara personal hygiene personal hygiene dengan infeksi telur cacing usus (Soil Transmitted Helmint) pada petani sayur di Kabupaten Gianyar ( $p$-value $>0,05$ ).
\end{abstract}

Kata Kunci: Personal Hygiene, Cacing Usus (Soil Transmitted Helmints), Petani Sayur 


\begin{abstract}
Soil Transmitted Helminths (STH) are intestinal nematode worms that infect humans who ingest their eggs via the faecal-oral route. Soil Transmitted Helminths (STH) infection is transmitted through eggs and larvae found in human feces which then contaminate the soil in environmental areas that have poor sanitation. The impact caused by worms includes malnutrition, growth and development disorders and cognitive disorders in children, and in adults it can reduce work productivity. The incidence of worms is found mainly in people living in rural areas, especially farmers. STH transmission to vegetable farmers occurs through water and sludge used in vegetable cultivation. STH prevalence is supported by suitable natural conditions, personal hygiene and low environmental sanitation, especially in the vegetable farming environment. This study aims to determine the relationship between personal hygiene and intestinal worm egg infection (Soil Transmitted Helmint) vegetable farmers in Gianyar Regency. The type of research used in this study is a descriptive correlative study with a cross sectional study approach which aims to determine the relationship between personal hygiene and intestinal worm infection (Soil Transmitted Helmint) in vegetable farmers in Gianyar Regency. The results showed that the personal hygiene condition of vegetable farmers in Gianyar Regency was poor $(83.3 \%)$ and the incidence of worm infection in vegetable farmers in Gianyar Regency was 20\%. There is no relationship between personal hygiene personal hygiene with intestinal worm egg infections (Soil Transmitted Helmint) in vegetable farmers in Gianyar Regency (p-value $>$ $0.05)$.
\end{abstract}

Keywords: Personal Hygiene, Egg Extraction (Soil Transmitted Helminths), Vegetable Farmers

\begin{tabular}{ll}
\hline Alamat Korespondensi & : STIKes Wira Medika Bali \\
Email & : iid_wika@yahoo.com
\end{tabular}

PENDAHULUAN

Permasalahan penyakit infeksi di Indonesia masih tergolong tinggi, terutama yang berkaitan dengan kondisi personal hygiene. Salah satu penyakit yang angka insidennya masih tinggi adalah penyakit infeksi yang disebabkan oleh cacing usus yang penularannya melalui tanah Soil Transmitted Helminthiasis (STH). Soil Transmitted Helminths (STH) merupakan cacing golongan nematoda usus yang menginfeksi manusia yang menelan telurnya melalui rute fekal oral. Ada lima jenis cacing nematoda usus yang penularannya melalui tanah, yaitu cacing gelang (Ascaris lumbricoides), cacing cambuk (Trichuris trichiura), cacing tambang (Necator americanus dan Ancylostoma duodenale), dan cacing benang (Strongyloides stercoralis) (WHO, 2018). Infeksi cacing Soil Transmitted Helminths (STH) ditransmisikan melalui telur dan larva yang terdapat pada feses manusia yang kemudian mengkontaminasi tanah area lingkungan yang memiliki sanitasi yang buruk (WHO, 2018).

Infeksi kecacingan yang disebabkan oleh Soil Transmitted Helminth (STH) masih menjadi masalah kesehatan bagi masyarakat Indonesia. Dampak yang ditimbulkan oleh penyakit kecacingan antara lain, yaitu kekurangan gizi, gangguan 
tumbuh kembang dan gangguan kognitif pada anak, dan pada orang dewasa bisa menurunkan produktifitas kerja (Kurniawan, 2010).

Kejadian kecacingan banyak ditemukan terutama pada penduduk yang berada di daerah pedesaan, khususnya pada petani. Faktor pekerjaan juga dapat mempengaruhi frekuensi penyakit kecacingan, terutama pekerjaan yang berhubungan atau menggunakan tanah. Pekerja yang selalu kontak langsung dengan tanah salah satunya pekerja kebun atau petani sayur yang mempunyai risiko tinggi terinfeksi penyakit menular (Ali et al, 2016). Para petani melakukan pekerjaan mulai dari kegiatan menanam, mencangkul, memupuk, dan memanen hasil. Pada setiap kegiatan tersebut mereka sangat berisiko terinfeksi cacing, baik melalui oral yaitu melalui makanan dan minuman yang tercemar, maupun melalui penetrasi kulit dengan adanya kontak langsung dengan kotoran hewan yang digunakan sebagai pupuk tanaman. Kotoran ternak mengandung telur dan larva cacing yang dapat menyebabkan gangguan pada sistem ekologis, di antaranya penyebaran penyakit cacingan terhadap manusia maupun ternak (Salim, 2013).

Penularan Soil Transmitted Helminth (STH) pada petani sayur terjadi melalui air dan lumpur yang digunakan dalam budidaya sayuran (Wijaya, 2015). Kontaminasi kecacingan dapat terjadi terutama pada sayuran yang menjalar di permukaan tanah atau ketinggiaannya dekat dengan tanah. Selain itu, para petani seringkali menggunakan pupuk organik berupa humus atau kotoran ternak (bahkan kotoran manusia) untuk meningkatkan kesuburan tanah (Amry et al, 2013). Selain itu, prevalensi Soil Transmitted Helminth (STH) didukung oleh keadaan alam yang cocok, personal hygiene dan sanitasi lingkungan yang rendah khususnya di lingkungan pertanian sayur (Wijaya, 2015).

Berdasarkan penelitian yang dilakukan Ali, at.al (2016) menunjukkan bahwa mayoritas pekerja sayur di Kelurahan Maharatu Pekan Baru positif terinfeksi cacing dengan Ascaris lumbricoides yang termasuk kategori infeksi ringan. Selain itu, penelitian menujukkan terdapat hubungan pemakaian Alat Pelindung Diri (APD), kebersihan kuku, mencuci tangan, penyedian air bersih, kepemilikan jamban dan saluran pembuangan limbah dengan kejadian penyakit cacing di Kelurahan Maharatu Pekan Baru.

Berdasarkan latar belakang diatas, maka penulis berkeinginan untuk melakukan penelitian tentang bagaimana hubungan antara personal hygiene dengan dengan infeksi telur cacing usus (Soil Transmitted Helmint) pada petani sayur di Kabupaten Gianyar.

\section{METODE PENELITIAN}

Penelitian ini dilakukan pada bulan Januari 2020 di Kabupaten Gianyar Bali. Jenis penelitian yang digunakan dalam penelitian ini adalah penelitian deskriptif korelatif dengan pendekatan cross sectional study yang bertujuan untuk mengetahui hubungan antara personal hygiene dengan infeksi cacing usus (Soil Transmitted Helmint) pada petani sayur di Gianyar. Populasi pada penelitian ini adalah seluruh petani sayur di Kabupaten Gianyar yang melakukan pekerjaan di sawah. Sampel pada penelitian ini adalah petani sayur di Kabupaten Gianyar yang melakukan pekerjaan di sawah. Sampel feses yang diambil sekitar 100 gram (sebesar ibu jari) untuk pemeriksaan infeksi telur cacing usus (Soil Transmitted Helmint) petani sayur 
di Gianyar. Penentuan responden menggunakan teknik purposive sampling yang memenuhi kriteria inklusi. Jenis data yang digunakan pada penelitian ini adalah data primer hasil pemeriksaan infeksi telur cacing yang diperoleh melalui pemeriksaan feses petani sayur dengan menggunakan metode langsung (direct method). Kondisi personal hygiene dilihat dengan menggunakan lembar kuesioner untuk wawancara terhadap responden. Analisa data yang digunakan yaitu analisis bivariat untuk menilai hubungan dua variabel yaitu hasil wawancara tentang kondisi personal hygiene dengan hasil pemeriksaan infeksi telur cacing menggunakan uji Uji Korelasi Spearman kemudian interpretasikan secara deskriptif.

\section{HASIL DAN PEMBAHASAN}

\section{HASIL PENELITIAN}

Tabel 1. Distribusi Frekuensi Responden Berdasarkan Personal Hygiene

\begin{tabular}{ccc}
\hline Personal Hygiene & Frekuensi & Persentase \\
\hline Baik & 5 & 16,7 \\
Buruk & 25 & 83,3 \\
\hline Jumlah & 30 & 100,0 \\
\hline
\end{tabular}

Tabel 2. Distribusi Frekuensi Responden Berdasarkan Pemeriksaan Terhadap Sampel Feses

\begin{tabular}{ccc}
\hline Pemeriksaan Feses & Frekuensi & Persentase \\
\hline $\begin{array}{c}\text { (-)Ascaris lumbricoides, Trichuris trichiura, } \\
\text { Ancylostoma duodenale } \\
(+) \text { Necator americanus }\end{array}$ & 24 & 80 \\
\hline Jumlah & 6 & 20 \\
\hline
\end{tabular}

Tabel 3. Hubungan antara Personal Hygiene dengan Infeksi Telur Cacing Usus (Soil Transmitted Helminths) pada Petani Sayur di Kabupaten Gianyar

\begin{tabular}{lccccccc}
\hline \multirow{2}{*}{$\begin{array}{c}\text { Personal } \\
\text { Hygiene }\end{array}$} & \multicolumn{4}{c}{ Kejadian Kecacingan } & \multicolumn{2}{c}{ Total } & \multirow{2}{*}{ Sig. p } \\
\cline { 2 - 6 } & \multicolumn{2}{c}{ Positif } & \multicolumn{2}{c}{ Negatif } & & & \\
\cline { 2 - 7 } & $\mathbf{N}$ & $\mathbf{\%}$ & $\mathbf{N}$ & $\mathbf{\%}$ & $\mathbf{N}$ & $\mathbf{\%}$ & \\
\hline Baik & 1 & 3,3 & 4 & 13,3 & 5 & 16,6 & 1,000 \\
Buruk & 5 & 16,7 & 20 & 66,7 & 25 & 83,4 & \\
\hline Jumlah & 6 & 20 & 24 & 80 & 30 & 100 & \\
\hline
\end{tabular}

\section{PEMBAHASAN}

Gambaran kondisi personal hygiene responden penelitian adalah secara keseluruhan buruk. Mencuci tangan dengan air bersih dan sabun. Kebersihan kuku dipotong seminggu sekali dan ketika kuku sudah panjang. Pemakaian Alat 
Pelindung Diri (APD) seperti sepatu dan hanscoon. Untuk melakukan analisis secara keseluruhan tentang kondisi personal hygiene, maka dilakukan skoring untuk menilai aspek-aspek personal hygiene tersebut. Dari hasil skoring tersebut diperoleh rerata skor kondisi personal hygiene petani sayur adalah 5 dengan skor terendah 0 dan tertinggi 5. Dengan menggunkan batasan kondisi personal hygiene "baik" apabila skor $\geq 5$ dan kondisi personal hygiene "buruk" apabila skor $<5$, maka diperoleh gambaran distribusi kondisi personal hygiene seperti pada tabel 1 diatas.

Berdasarkan hasil pemeriksaan feses petani sayur di Kabupaten Gianyar sebanyak 30 orang menunjukkan bahwa petani sayur yang terinfeksi telur cacing Soil Transmitted Helminths (STH) berjumlah 6 orang $(20 \%)$ dan yang tidak terinfeksi berjumlah 24 orang (80\%). Jenis telur cacing Soil Transmitted Helminths (STH) yang menginfeksi adalah spesies Necator americanus (cacing tambang). Produksi telur cacing Necator americanus (cacing tambang) perhari 9.000 sampai 10.000 telur (Rusmartini, 2009).

Analisis hasil pemeriksaan feses dan kuesioner kondisi personal hygiene dengan uji Korelasi Spearman menunjukkan tidak adanya korelasi antara personal hygiene dengan infeksi telur cacing usus (Soil Transmitted Helminth) pada petani sayur di Kabupaten Gianyar (nilai $-p>0,05$ ).

Hasil penelitian ini tidak sama dengan penelitian Maulidiyah Salim (2013) yang menyatakan bahwa mayoritas pekerja sayur di Kelurahan Maharatu positif terinfeksi cacing mengalami penyakit cacing Soil Transmitted Helminths (STH) dengan spesies Ascaris lumbricoides yang tergolong infeksi ringan. Terdapat hubungan pemakaian Alat Pelindung Diri (APD), Kebersihan kuku, mencuci tangan, penyedian air bersih, kepemilikan jamban dan saluran pembuangan limbah dengan kejadian penyakit cacing di Kelurahan Maharatu (Ali et al, 2016). Hasil yang tidak sama juga ditunjukkan pada penelitian Ivan et.al (2019) yang menyatakan bahwa terdapat hubungan signifikan antara penggunaan APD pada pekerja perkebunan Kaliputih dengan status infeksi Soil Transmitted Helminths (STH).

Personal Hygiene adalah suatu tindakan untuk memelihara kebersihan dan kesehatan. Personal hygiene ini menjadi penting karena Personal hygiene yang baik akan meminimalkan pintu masuk (portal of entry) mikroorganisme yang ada dimana-mana dan pada akhirnya mencegah seseorang terkena penyakit (Suraini et.al, 2018).

\section{SIMPULAN DAN SARAN}

Berdasarkan hasil penelitian ini maka dapat ditarik simpulan, yaitu kondisi Personal hygiene petani sayur di Kabupaten Gianyar buruk (83,3\%). Spesies Soil Transmitted Helminths (STH) yang menginfeksi petani sayur di Kabupaten Gianyar adalah telur cacing Necator americanus (cacing tambang) sebanyak 6 (20\%). Tidak terdapat hubungan antara personal hygiene dengan kejadian infeksi cacing Soil Transmitted Helminths (STH) pada petani sayur di Kabupaten Gianyar dengan nilai nilai $-p>0,05$. Saran pada hasil penelitian ini adalah petani sayur lebih meningkatkan personal hygiene pada saat bekerja maupun setelah bekerja dengan selalu menjaga kebersihan tangan dengan mencuci tangan, menjaga kebersihan kuku, menggunakan APD (Alat Pelindung Diri) pada saat bekerja berupa sarung tangan dan sepatu boot dan melakukan pemeriksaan kesehatan secara berkala. 


\section{UCAPAN TERIMAKASIH}

Melalui kesempatan ini penulis menyampaikan ucapan terimakasih kepada petani sayur di Kabupaten Gianyar. Laboratotium STIKes Wira Medika Bali, Ni Nengah Sukerti, serta semua pihak atas saran dan kritiknya sehingga penelitian ini dapat terselesaikan

\section{DAFTAR PUSTAKA}

Ali, R. U., Zulkarnaini, dan D. Affandi. 2016. Hubungan personal hygiene dan sanitasi lingkungan dengan angka kejadian kecacingan (Soil Transmitted Helminth) pada petani sayur di Kelurahan Maharatu Kecamatan Marpoyan Damai Kota Pekanbaru. Dinamika Lingkungan Indonesia 3(1): 24-32.

Amry, J., Ruslan, Makmur, S. 2013. Gambaran Parasit Soil Transmitted Helminths dan Tingkat Pengetahuan, Sikap serta Tindakan Petani Sayur di Desa Waiheru Kecamatan Baguala Kota Ambon. Reporsitory UNHAS.

Ivan Iqbal Baidowi, Yunita Armiyanti , Zahrah Febianti, Bagus Hermansyah, Yudha Nurdian. 2019. Hubungan Penggunaan Alat Pelindung Diri Dengan Status Infeksi Soil-Transmitted Helminths Pada Pekerja Kebun Di Perkebunan Kaliputih Kabupaten Jember. Journal of Agromedicine and Medical Sciences. 5(2): 61-68.

Kurniawan,A.(2010). Infeksi Parasit: Dulu dan Masa Kini. Majalah Kedokteran Indonesia.

Rusmartini T. 2009. Parasitologi kedokteran: ditinjau dari organ tubuh yang diserang. Jakarta: EGC

Salim, M. 2013. Faktor-faktor yang Berhubungan dengan Positif Telur Cacing Soil Transmitted Helminths (STH) pada Petani Pengguna Pupuk Kandang di Desa Rasau Jaya Umum Tahun 2013. Pontianak.

Suraini, Kaselawaty Dan Fitra Wahyuni. 2018. Pengaruh Pengetahuan Dan Personal Hygiene Terhadap Kejadian Infeksi Cacing Pada Murid Sdn 50 Kampung Jambak Padang. Prosiding Seminar Kesehatan Perintis. 1(1).

Wijaya, N. H. 2015. Beberapa Faktor Risiko Kejadian Infeksi Cacing Tambang Pada Petani Pembibitan Albasia. Institutional Reporsitory UNDIP. Semarang.

World Health Organization 2018. Soil- Transmitted Heminth Infections. http://www.who.int/en/new-room/fact-sheets/detail/soil-transmittedhelminth-infections. (Diakses pada 10 September 2020). 